\title{
Prediksi Kuota Pemesanan Bahan Bakar Pada SPBU dengan Metode Regresi Linear Berganda
}

\author{
Abdurrasyid1; Indrianto2; Meilia Nur Indah Susanti3 \\ ${ }^{1,2,3}$ Institut Teknologi PLN \\ arasyid@itpln.ac.id
}

\begin{abstract}
Fuel oil becomes an important commodity in running the economy of a country, the Downstream Oil and Gas Regulatory Agency (BPH MIGAS) noted that Indonesia spent 28.25 million kiloliters within 2019, this figure was compiled from all public refueling stations which are downstream of fuel distribution to the public, but on the other side of the Gas station is often out of stock due to lack of control over stocks, the impact is a long queue of people at the Gas station, for gas stations that are out of stock obviously will reduce the revenue because there is no sale during the delivery process from upstream to downstream, then it takes a system that can help predict how much quota should be ordered so that the out of stock condition does not occur, multiple liner regression method is used to predict fuel quota As for the variable used there are two independent variables namely residual stock (W1), incoming stock (W2) and two dependent variables used that is stock out (Y). After the classic assumption test can be concluded that independent variables (W1 and W2) positively affect dependent variables (Y). Testing was conducted using MAPE (Mean Absolute Percent Error) method after testing obtained error results for pertalite fuel by $11.0 \%$ and diesel by $13.2 \%$.
\end{abstract}

Keywords: Multiple Linier Regression, Stock Prediction, Gas Station, Fuel, MAPE

ABSTRAK

Bahan bakar minyak menjadi komoditi penting dalam menjalankan roda perekonomian suatu negara, data Badan Pengatur Hilir Minyak dan Gas(BPH MIGAS) mencatat Indonesia menghabiskan 28,25 juta kiloliter selama tahun 2019, angka ini dihimpun dari seluruh Stasiun Pengisian Bahan Bakar Umum (SPBU) yang menjadi hilir distribusi BBM kepada masyarakat, namun disisi lain SPBU sering kehabisan stok karna kurangnya pengendalian terhadap stok, dampaknya adalah antrian panjang masyarakat di SPBU, bagi SPBU yang kehabisan stok jelas akan mengurangi pemasukan karna delay tidak ada penjualan selama proses pengiriman dari hulu ke hilir, maka dibutuhkan adanya sistem yang mampu membantu memprediksi berapa kuota yang harus dipesan sehingga kondisi out of stock tidak terjadi, metode regresi liner berganda digunakan untuk memprediksi kuota bahan bakar Adapun variable yang digunakan terdapat dua variabel independent yaitu stok sisa (W1), stok masuk (W2) dan dua variabel dependent yang digunakan yaitu stok keluar (Y). Setelah dilakukan uji asumsi klasik dapat disimpulkan bahwa variabel independent (W1 dan W2) berpengaruh positif terhadap variabel dependent (Y). Pengujian dilakukan dengan menggunakan metode MAPE (Mean Absolute Percent Error) setelah dilakukan pengujian diperoleh hasil error untuk bahan bakar pertalite sebesar 11,0\% dan solar sebesar 13,2\%.

Kata kunci: Regresi Linier Berganda, Prediksi Stok, SPBU, Bahan Bakar, MAPE 


\section{PENDAHULUAN}

Bahan bakar minyak menjadi komoditi penting dalam menjalankan roda perekonomian suatu negara, data Badan Pengatur Hilir Minyak dan Gas(BPH MIGAS) mencatat Indonesia menghabiskan 28,25 juta kiloliter selama tahun 2019[1], angka ini dihimpun dari seluruh Stasiun Pengisian Bahan Bakar Umum (SPBU) yang menjadi hilir distribusi BBM kepada masyarakat, namun disisi lain SPBU sering kehabisan stok karna kurangnya pengendalian terhadap stok, dampaknya adalah antrian panjang masyarakat di SPBU, bagi SPBU yang kehabisan stok jelas akan mengurangi pemasukan karna delay tidak ada penjualan selama proses pengiriman dari hulu ke hilir.

Dalam proses pengiriman dan pendistribusian dari Hulu ke hilir, dilapang tidak sedikit terjadi permasalahan seperti terjadi kelangkaan bahan bakari yang diakibatan karena kebutuhan masyarakat lebih tinggi dari jumlah pasokan yang dikirim sehingga tentu kejadian ini dapat menghentikan proses produksi yang dilakukan oleh perusahaan dan mengganggu kelangsungan usaha bisnis kecil, disamping harga BBM yang fluktuatif, tidak sedikit juga beredar BBM ilegal dan lain-lain. Jika permasalahan diatas berlangsung terus-menerus maka akan mengganggu roda perekonomian, untuk itu dibutuhkan sistem yang dapat membantu memprediksi berapa kuota yang harus dipesan sehingga kondisi out of stock tidak terjadi.

Kegiatan peramalan sangat dibutuhkan dalam berbagai macam situasi, saat hendak membangun pembangkit listrik, penentuan kebutuhan yang akan dating termasuk untuk melakukan peramalan terhadap stok yang dibutuhkan dimasa yang akan dating, namun untuk melakukan peramalan itu tentu diperlukan faktor yang berpengaruh terhadap peramalan, dan data yang tersedia.

Dari permasalahan di atas, proses peramalan perlu di lakukan di PT. Pertamina (Persero) khususnya untuk kegiatan penjualan bahan bakar minyak terutama pada setiap SPBU hal ini daharapkan dapat membantu dalam menentukan besar stok bahan bakar yang harus dikirium untuk hari berikutnya. Disamping itu dibutuhkan alat yang digunakan untuk melakukan memonitoring terhadap stok bahan bakar secara terkomputerisasi yang diharapkan dapat membantu mempermudah petugas di setiap SPBU.

Penelitian dilakukan untuk melakukan merancang dan membangun perangkat lunak yang dapat membantu meramalkan stok bahan bahan bakar yang akan datang, dengan mengimplementasikan metode regresi linear berganda untuk melakukan peramalan stok bahan bakar.

Penelitian yang sebelumnya pernah dilakukan oleh puspitasari pada tahun 2019 melakukan estimasi penerimaan bahan bakar dengan menggunakan metode Fuzzy Tsukamoto[2], selain estimasi bahan bakar ada juga penelitian yang dilakukan olehYulius pada tahun 2016 penelitian ini menerapkan metode peramalan dan economic order quantity untuk melakukan pengendalian terhadap perencanaan produksi bahan bakar premium serta harga pemesanan crude oil ekonomis [3], selain itu Sa'adah pada tahun 2016 melakukan menerapkan metode sistem dinamik untuk melakukan peramalan terhadap penyediaan dan konsumsi bahan bakar minyak di indonesia [4], dan Siregar ditahun 2015 membuat web aplikasi dan sms gateway yang digunakan untuk memonitor tangki bahan bakar minyak spbu [5], serta prediksi pengadaan barang di PT. Pertamina dengan menggunakan metode fuzzy Mamdani [6] dari penelitian yang telah dilakukan sebelumnya menunjukan bahwa penelitian ini memiliki keterbaruan dalam pemanfaatan metode yang diterapkan dalam melakukan prediksi pada objek penelitian pemesanan bahan bakar.

Metode regresi linier berganda sebagai metode peramalan yang memiliki tingkat akurasi yang cukup baik digunakan dalam penelitian ini, terbukti pada penelitian yang dilakukan oleh Feng pada tahun 2017 dalam memprediksi kebutuhan rental sepeda didapatkan tingkat akurasi hingga 82 persen[7], tidak berbeda jauh dengan yang dilakukan oleh Triyanto pada tahun 2019 yang menggunakan metode ini untuk memprediksi produksi padi di Kabupaten Bantul didapatkan deviasi 
10 persen[8], hal yang sama dibuktikan oleh Muda pada tahun 2019 yang menggunakan metode ini untuk memprediksi anggaran pembelian obat, didapatkan tingkat akurasi hingga 90,84 persen[9]

\section{METODE/PERANCANGAN PENELITIAN}

\subsection{Metode Regresi Linier Berganda}

Metode regresi linier berganda merupakan metode yang cukup sering digunakan untuk melakukan prediksi seperti memprediksi angka kelahiran di kota Kendari [10], penjualan smartphone[11] dan dapat juga di kombinasikan pada data mining untuk memprediksi persediaan buku[12].

Regresi linear berganda berfungsi untuk mengukur tingkat akurasi keterkaitan antara lebih dari satu variable bebas dengan variabel terikat yang merupakan variabel yang akan diramalkan. Metode regresi linear berganda yang digunakan pada penelitian ini memiliki dua variable bebas dan dua variable terikat, variable bebas yang digunakan adalah stok sisa (W1) dan stok masuk (W2). Sedangkan variable yang hendak diramal adalah stok keluar (Y). Pada tahap ini pengujian dilakukan untuk melihat bagaimana variabel yang diramalkan yaitu stok keluar (Y) dapat dipengaruhi secara positif oleh variabel bebas stok sisa (W1) dan stok masuk (W2). Data yang digunakan dalam dalam penelitian ini menggunakan data manajemen stok bahan bakar minyak pada SPBU dengan durasi selama tujuh hari. Adapun rumus persamaan dari regresi linear berganda yang yang digunakan dapat dilihat pada persamaan dibawah ini.

$$
Y=b 1+b 2 W 1+b 3 W 2+b k W k
$$

$$
\begin{array}{ll}
\operatorname{Dimana}: \mathrm{Y} & =\text { variabel terikat }(\text { dependent) } \\
\mathrm{b} 1, \ldots, \mathrm{bk} & =\text { koefisien regresi } \\
\mathrm{W} 1, \ldots, \mathrm{Wk} & =\text { variabel bebas (independent) }
\end{array}
$$

\subsection{Kerangka Pemikiran}

Gambar 1 menjelaskan kerangka pemikiran dari penelitian yang dilakukan. Diawali dengan adanya masalah yakni belum dilakukannya peramalan terhadap penjualan bbm dengan metodemetode tertentu dan disamping belum adanya sistem untuk memonitor tangki bahan bakar secara terkomputerisasi. Penelitian dilakukan bertujuan untuk membantu petugas SPBU mengetahui prediksi penjualan bahan bakar khususnya jenis pertalite dan solar. Setelah didapatkan prediksi berikutnya petugas SPBU dapat mengambil estimasi berapa stok yang dibutuhkan untuk hari berikutnya.

UML (Unified Modelling Language) digunakan untuk analisis pengembangan perangkat lunak menggunakan. UML menjelaskan bagaimana fitur dan hubungan antara antara objek dalam pengembangan perangkat lunak. Karna alat yang dibuat diintegrasikan dengan perangkat lunak berupa web maka dibuat dengan Bahasa pemrogramam PHP. Sedangkan untuk membangun alat menggunakan bahasa Pemrograman python.

Untuk memastikan baik alat ataupun perangkat lunak dapat bekerja maka dilakukan pengujian, Adapun pengujian yang dilakukan yang pertama menguji perangkat keras, selanjutnya menguji apakah metode regresi linier dapat berjalan sesuai harapan dengan membandingkan dengan data actual digunakan metode pengujian MAPE( Mean Absoluter Persentage Error), serta yang terakhir adalah pengujian perangkat lunak dengan menguji fungsionalitas yang dimiliki oleh perangkat lunak dengan menggunakan metode black box. 


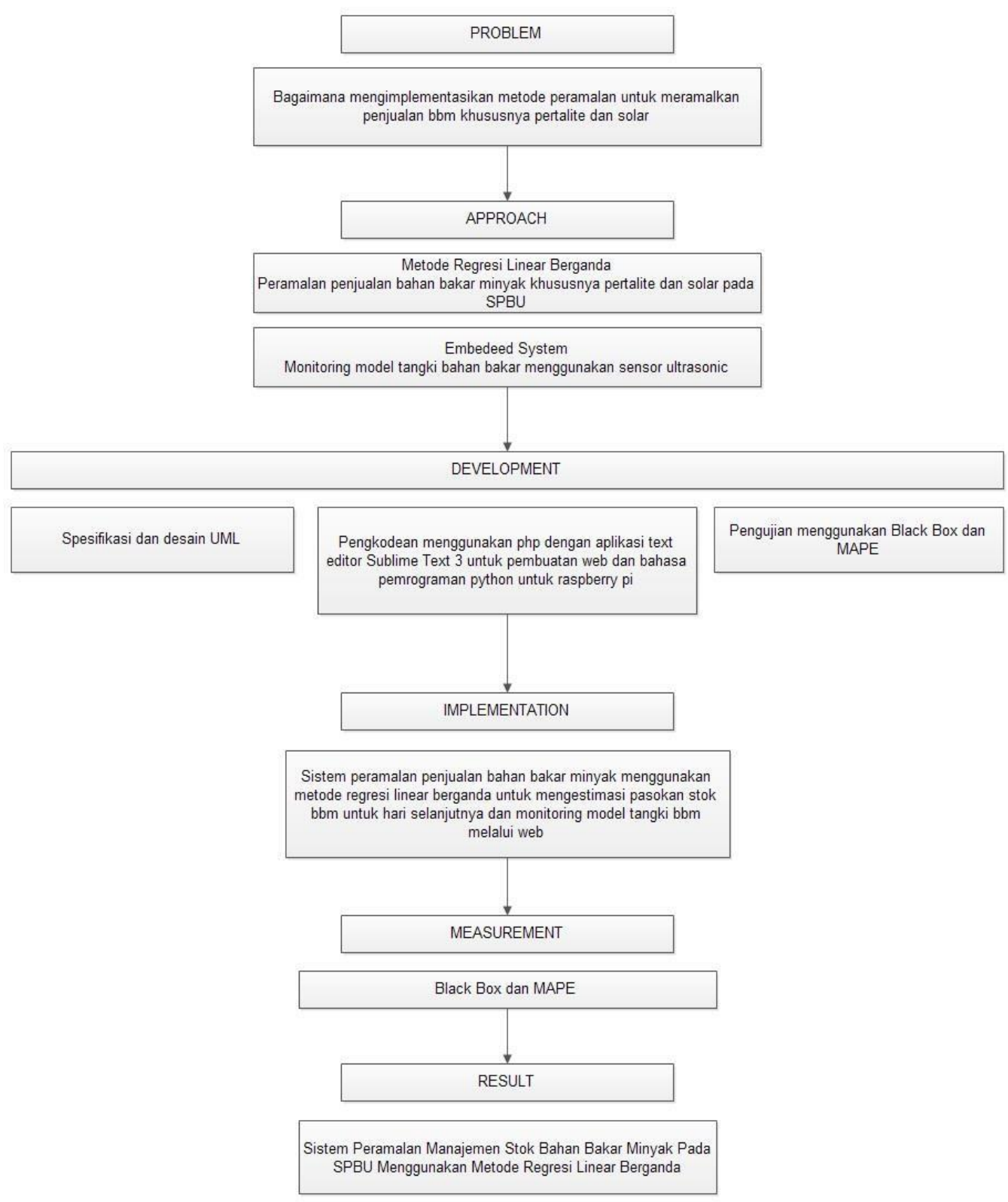

Gambar 1. Kerangka Pemikiran

Untuk lebih jelas mengenai tahapan langkah demi langkah penelitian ini dilakukan dapat dilihat pada gambar 2 dibawah ini, dimana tahapan dimulai dari Analisa kebutuhan dilanjutkan dengan Analisa data, lalu perancangan sistem dimana pada tahap ini mulai diimplementasikan metode regresi linier berganda kedalam perangkat lunak, selanjutnya pengujian baik itu pengujian akurasi sensor dan metode regresi linier berganda, serta pengujian fungsional perangkat lunak dengan menggunakan metode blackbox. 


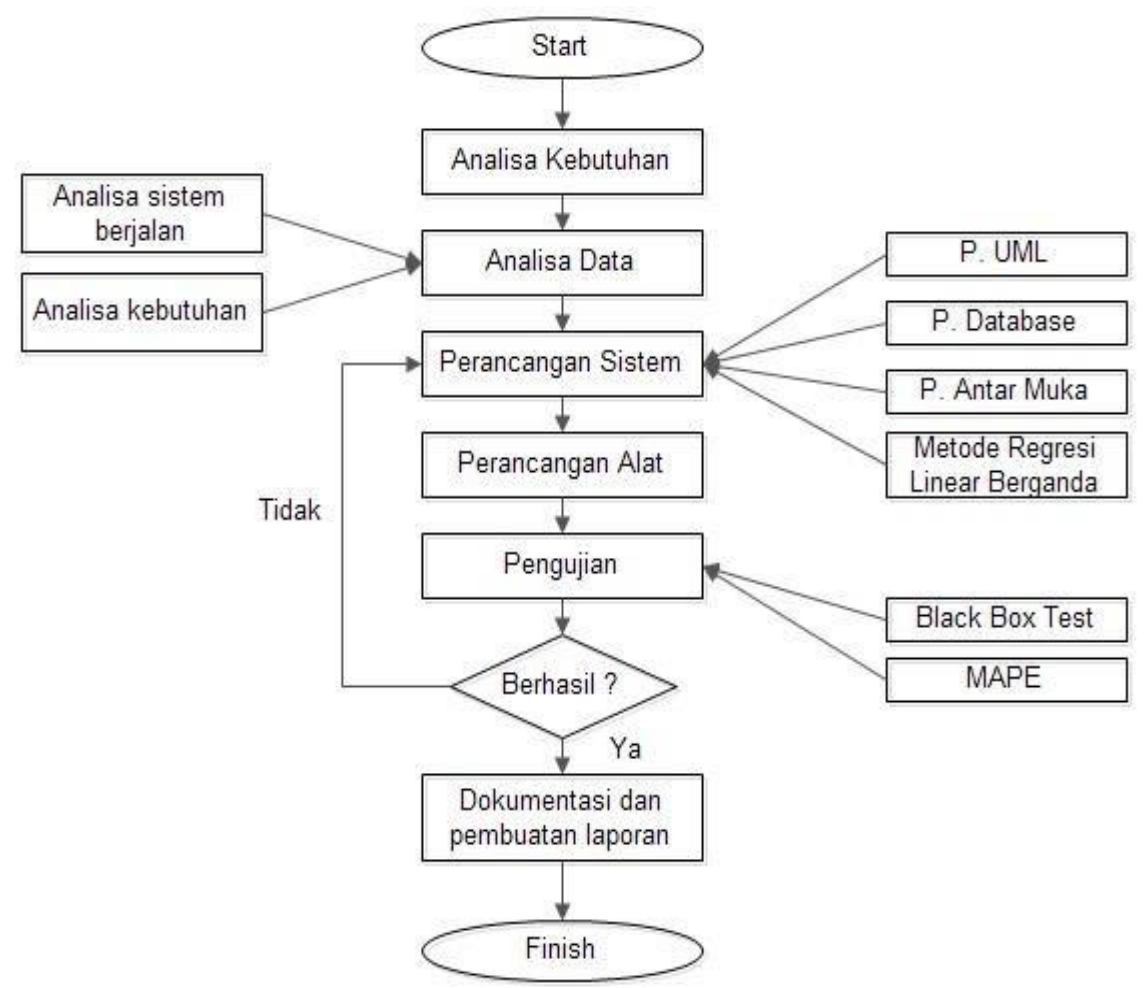

Gambar 2. Tahapan Penelitian

\subsection{Rancangan alat dan perangkat lunak}

Pada bagian ini dibuat rancangan alat dan perangkat lunak yang dapat mengakomodir kebutuhan dari pengguna, untuk alat dibuat dalam bentuk model sedangkan perangkat lunak dibuat dalam bentuk web sehingga dapat diakses dengan mudah, gambar 3 dibawah menunjukan model alat yang dibuat untuk mendeteksi stok bahan bakar yang tersedia pada tangki penyimpanan dengan menggunakan sensor ultrasonic.

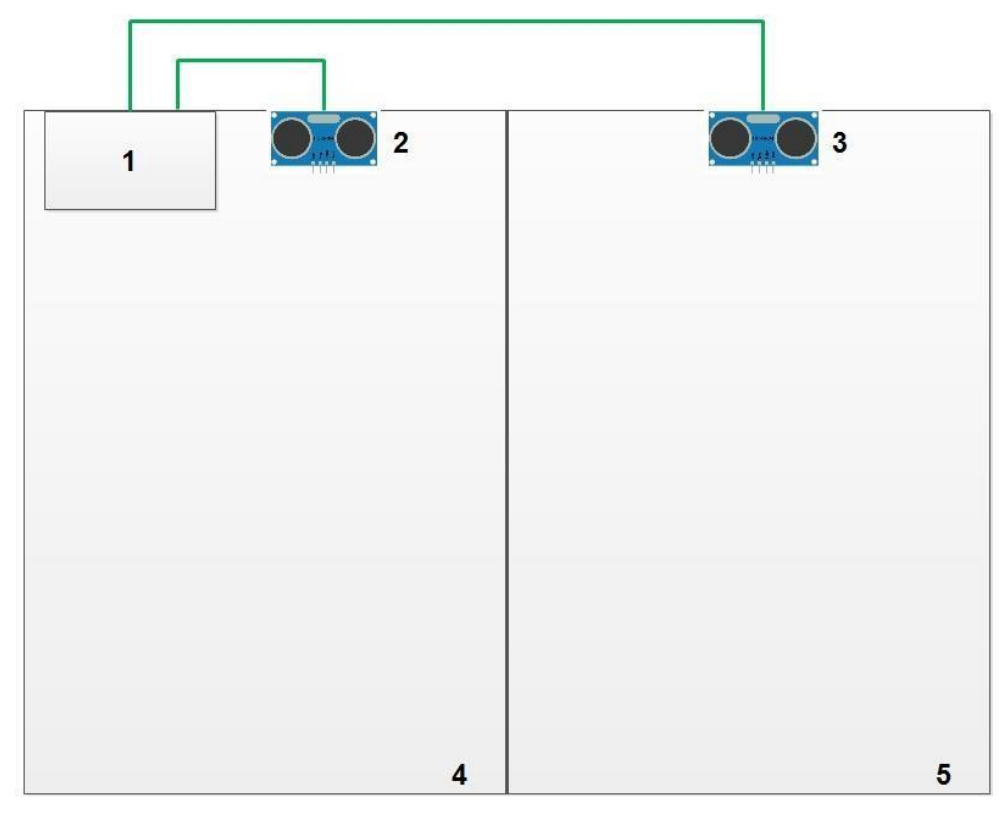

Gambar 3. Rancangan Alat 
Adapun use case dari perangkat lunak yang dibuat dapat dilihat pada gambar 4 dibawah ini.

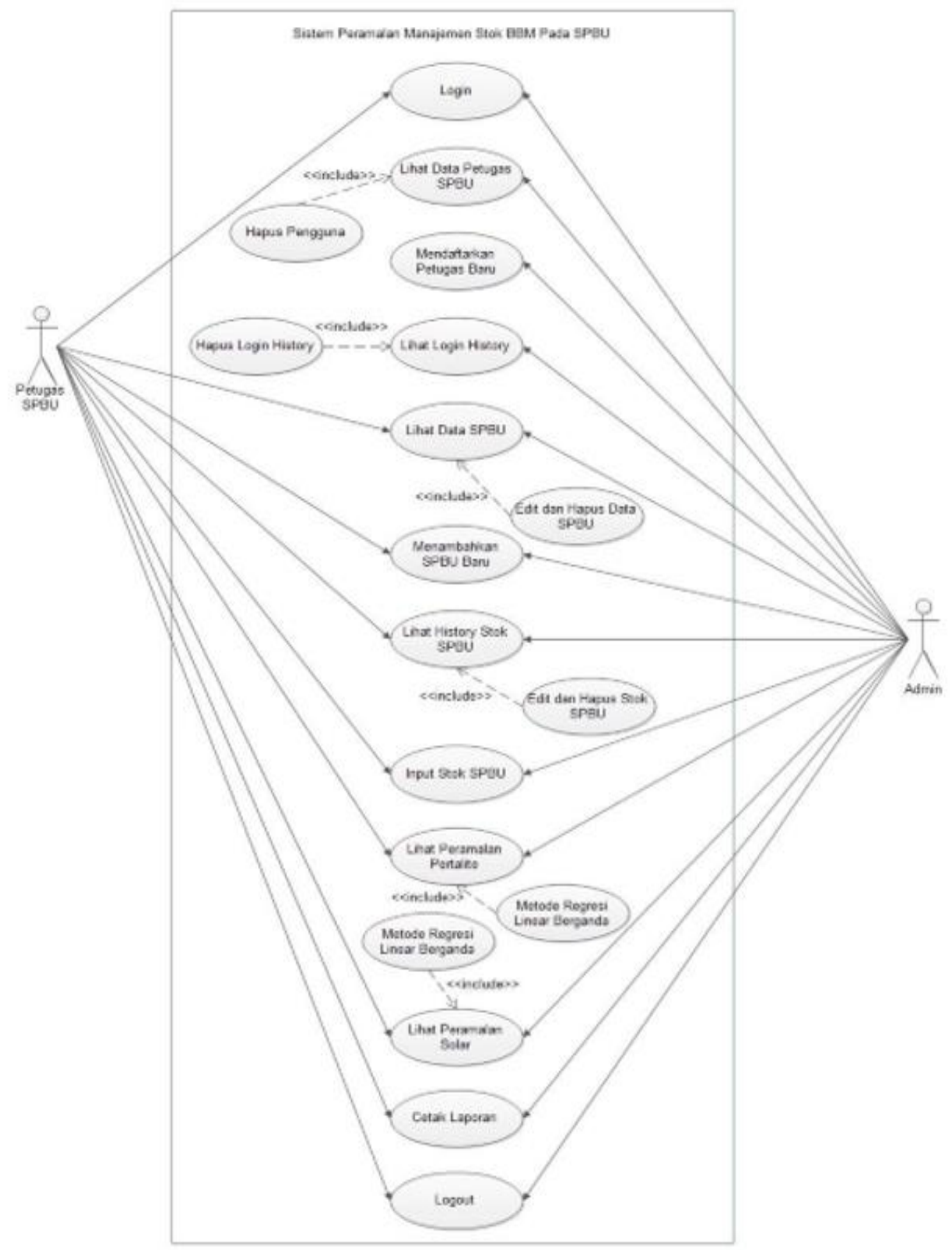

Gambar 4. Usecase 


\section{HASIL DAN PEMBAHASAN}

\subsection{Hasil pengujian}

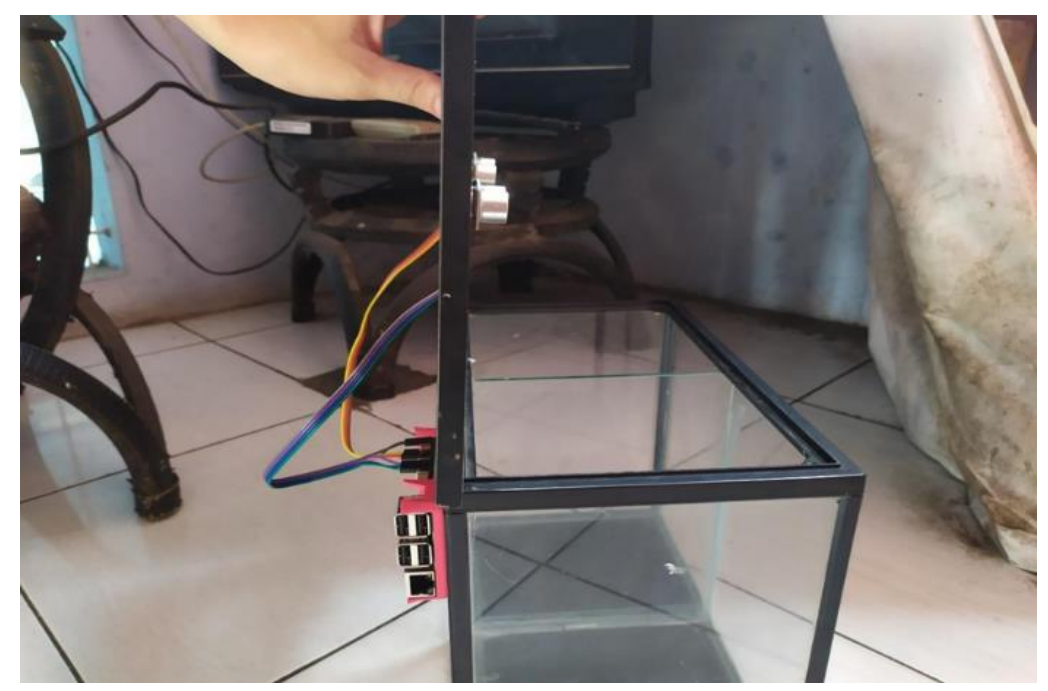

Gambar 5. Hasil alat

Gambar 5 menunjukan hasil dari model rangkaian alat yang dapat digunakan untuk melakukan monitoring terhadap stok bahan bakar, yang diintegrasikan dengan perangkat lunak yang dapat melakukan peramalan yang mengimplementasikan metode regresi linear berganda. Wadah untuk menampung air menggunakan box kaca berukuran lebar $18 \mathrm{~cm}$, panjang $30 \mathrm{~cm}$ dan tinggi $20 \mathrm{~cm}$. Box dibagi menjadi dua bagian, dimana setiap bagiannya berukuran lebar $18 \mathrm{~cm}$, panjang $15 \mathrm{~cm}$ dan tinggi $20 \mathrm{~cm}$, Adapun untuk mengukur ketinggian cairan digunakan sensor ultrasonic yang diletakkan pada setiap bagian.

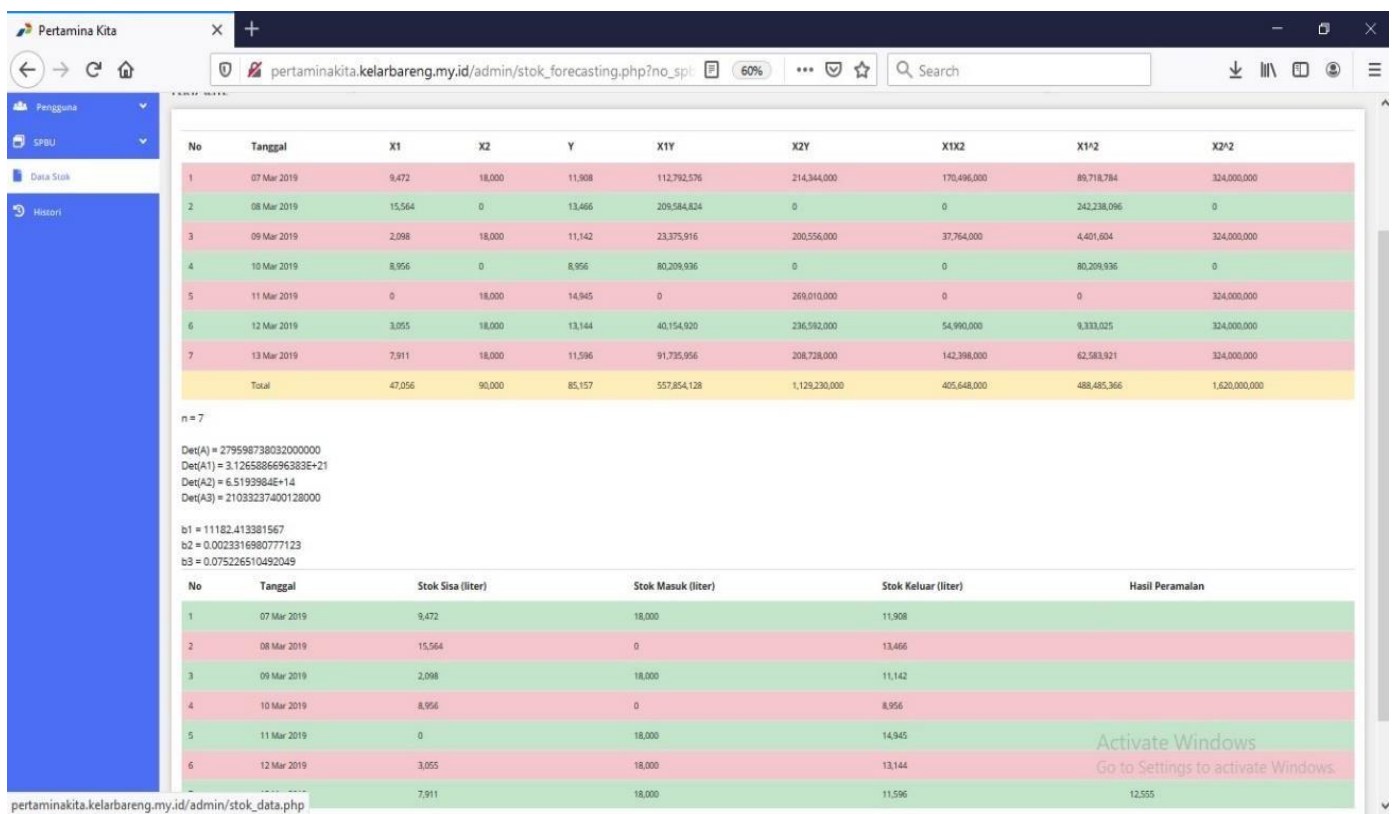

Gambar 6. Tampilan peramalan bahan bakar pada web

Gambar 6 menunjukan halaman web peramalan yang disediakan pada menu data stok. User dapat melihat hasil peramalan penjualan bahan bakar untuk hari berikutnya. Petugas SPBU dapat 
memanfaatkan hasil dari peramalan untuk mengestimasi berapa bahan bakar yang harus dipesan untuk hari berikutnya.

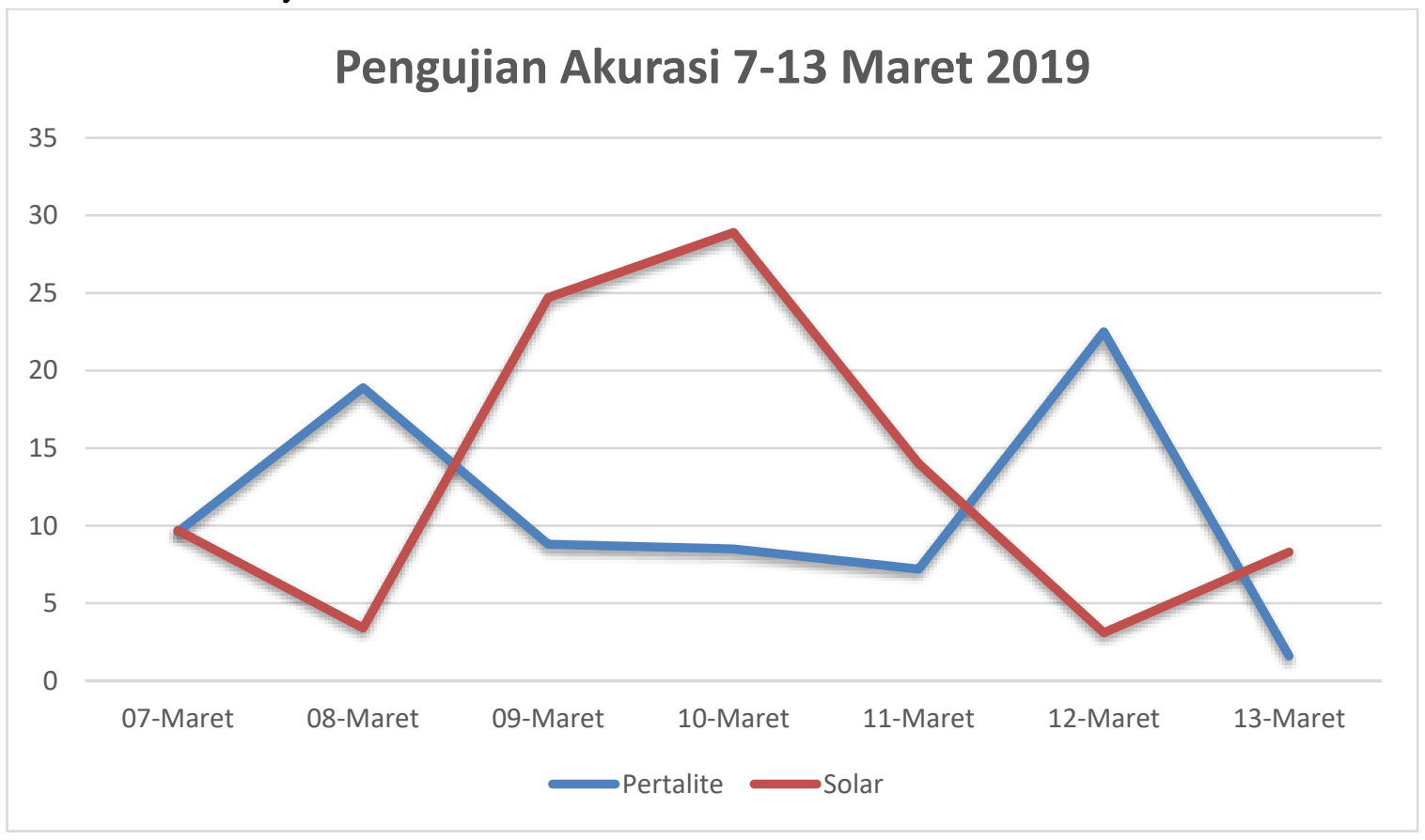

Gambar 7. Hasil pengujian akurasi regresi linier berganda

Dari hasil pengujian didapatkan tingkat rata-rata deviasi error ada pada nilai 11 persen untuk pertalite dan 13.2 persen untuk solar, sehingga dapat disimpulkan bahwa metode regresi linier cukup baik dalam melakukan peramalan terhadap penjualan bahan bakar, khususnya pada kasus ini bahan bakar solar dan pertalite dan tidak menutup kemungkinan dapat digunakan pada jenis bahan bakar lainnya.

\section{KESIMPULAN DAN SARAN}

Penelitian ini menerapkan metode regresi linear berganda untuk memprediksi berapa stok yang perlu dipesan pada waktu yang akan datang. Penelitian ini diawali dengan melakukan analisis terhadap sistem berjalan, analisis terhadap sistem usulan, melakukan perancangan sistem, dilanjutkan dengan perancangan alat dan diakhiri dengan tahapan pengujian terhadap perangkat keras, perangkat lunak dan akurasi metode regresi linier berganda. Data yang digunakan untuk proses prediksi penyediaan bahan bakar menggunakan data periode tujuh hari sebelumnya, selanjutnya diolah untuk mendapatkan hasil prediksi. Berikutnya hasil prediksi dapat untuk pemesanan dihari berikutnya.

Untuk menguji gap error peramalan yang dibuat dibandingkan dengan data actual digunakan metode MAPE (Mean Absolute Percent Error) dari hasil pengujian didapatkan tingkat error sebesar $13,2 \%$ pada peramalan pertalite dan $11,0 \%$ pada peramalan solar. Pengujian akurasi sistem monitoring tangki bahan bakar minyak untuk tangki pertalite didapatkan sebesar $91,20 \%$ dan untuk tangki solar sebesar $92,06 \%$.

Penelitian selanjutnya diharapkan dapat menggunakan variable lainnya yang memiliki pengaruh terhadap penjualan bahan bakan sehingga hasil prediksi menjadi lebih baik lagi, disamping perlu menguji keamanan sensor ultrasonic pada kondisi sebenarnya.

\section{UCAPAN TERIMAKASIH}


Ucapan Terima kasih kepada Lembaga Penelitian dan Pengabdian kepada Masyarakat Institut Teknologi PLN yang telah membantu dalam pendanaan penelitian ini melalui skema penelitian unggulan perguruan tinggi.

\section{DAFTAR PUSTAKA}

[1] BPH MIGAS, “LAPORAN KINERJA BPH MIGAS TAHUN 2019,” 2020.

[2] N. Puspitasari, A. Tejawati, and F. Prakoso, "Estimasi Stok Penerimaan Bahan Bakar Minyak Menggunakan Metode Fuzzy Tsukamoto," JRST (Jurnal Ris. Sains dan Teknol., vol. 3, no. 1, p. 9, 2019.

[3] H. Yulius and D. D. Putra, "Pengendalian Perencanaan Produksi Premium Dan Harga Pesan Crude Oil Ekonomis Menggunakan Metode Peramalan Dan Economic Order Quantity ( Studi Kasus Di PT Pertamina RU II Dumai)," J. Edik Inf., vol. 2, pp. 1-11, 2016.

[4] A. Fitriyatus, A. Fauzi, and B. Juanda, "Prediction ofFuel Supply and Consumption in Indonesia with System Dynamics Model," J. Ekon. dan Pembang. Indones., vol. 17, no. 2, pp. 118-137, 2018.

[5] R. R. A. Siregar and R. Raymond, "Model Sistem Monitoring Tangki Bahan Web Aplikasi Dan Sms Gateway," vol. 12, 2015.

[6] A. Abdurrasyid, M. N. I. Susanti, and D. S. Ningsih, "IMPLEMENTASI METODE FUZZY MAMDANI PADA APLIKASI INVENTORY UNTUK PREDIKSI PENGADAAN BARANG DI PT. PERTAMINA (PERSERO) PERKAPALAN,” PETIR, vol. 10, no. 2, pp. $1-8,2017$.

[7] Y. Feng and S. Wang, "A forecast for bicycle rental demand based on random forests and multiple linear regression," Proc. - 16th IEEE/ACIS Int. Conf. Comput. Inf. Sci. ICIS 2017, pp. 101-105, 2017.

[8] E. Triyanto, H. Sismoro, and A. D. Laksito, "IMPLEMENTASI ALGORITMA REGRESI LINEAR BERGANDA UNTUK MEMPREDIKSI PRODUKSI PADI DI KABUPATEN BANTUL," J. Teknol. dan Sist. Inf. Univrab, vol. 4, no. 2, pp. 73-86, 2019.

[9] M. Angelo, D. Muda, A. Affandi, and Y. K. Suprapto, "Forecasting Medicine Purchase Budget using Multiple Linear Regression Method : Case Study - For Ende Regency Health Office," no. Icasess 2019, pp. 186-192, 2020.

[10] L. . T. Nike Syafitri, Sutardi, "Aplikasi Forecasting Mengenai Angka Kelahiran di Kota Kendari Menggunakan Metode Regresi Linear Berganda (Studi Kasus: Dinas Kesehatan Kota Kendari)," Inform. Jur. Tek. Tek. Fak. Oleo, Univ. Halu, vol. 4, no. 1, pp. 31-38, 2018.

[11] T. Indarwati, T. Irawati, and E. Rimawati, "Penggunaan Metode Linear Regression Untuk Prediksi Penjualan Smartphone," J. Teknol. Inf. dan Komun., vol. 6, no. 2, pp. 2-7, 2019.

[12] I. L. L. Gaol, S. Sinurat, and E. R. Siagian, "Implementasi Data Mining Dengan Metode Regresi Linear Berganda Untuk Memprediksi Data Persediaan Buku Pada Pt. Yudhistira Ghalia Indonesia Area Sumatera Utara," KOMIK (Konferensi Nas. Teknol. Inf. dan Komputer), vol. 3, no. 1, pp. 130-133, 2019. 